\title{
The Influencing Factors of Financial Support Efficiency of New Generation High-Tech Industry in China: Evidence from Listed Companies
}

\author{
Mu Zhang1, Zhiyuan Lv',2 \\ ${ }^{1}$ School of Big Data Application and Economics, Guizhou University of Finance and Economics, Guiyang, China \\ ${ }^{2}$ Guizhou Institution for Technology Innovation \& Entrepreneurship Investment, Guizhou University of Finance and Economics, \\ Guiyang, China \\ Email: zhangmu01@163.com
}

How to cite this paper: Zhang, M., \& Lv, Z. Y. (2021). The Influencing Factors of Financial Support Efficiency of New Generation High-Tech Industry in China: Evidence from Listed Companies. Theoretical Economics Letters, 11, 771-788.

https://doi.org/10.4236/tel.2021.114050

Received: July 5, 2021

Accepted: August 17, 2021

Published: August 20, 2021

Copyright $\odot 2021$ by author(s) and Scientific Research Publishing Inc. This work is licensed under the Creative Commons Attribution International License (CC BY 4.0).

http://creativecommons.org/licenses/by/4.0/

\begin{abstract}
In order to improve the financial support efficiency of new generation high-tech industry in China, from the perspective of the subject (enterprise) in which financial resources were invested, this paper selected 192 listed companies in quantum communication and artificial intelligence concept plates in Chinese stock market as samples. Based on the original data of 2015-2019, the influencing factors of financial support efficiency of new generation high-tech listed companies were then empirically analyzed by using DEA-BCC model and Tobit model. The results showed that the ownership concentration, executive compensation and regional digital inclusive finance level were main factors affecting the financial support efficiency of new generation high-tech listed companies, followed by the technological innovation capability and regional economic development level. However, the influence of growth and comprehensive leverage were limited, and the influence of profitability and capital structure were not obvious. Accordingly, the main countermeasures to improve the financial support efficiency of new generation high-tech industry were proposed, which included giving full play to the advantages and potential of digital inclusive finance, actively guiding enterprises to innovate management, improve quality and efficiency, etc.
\end{abstract}

\section{Keywords}

New Generation High-Tech Industry, Listed Company, Financial Support Efficiency, Influencing Factor, Tobit Model 


\section{Introduction}

With the rapid development of high technology in the fields of electronic information, biology and new medicine, aerospace, new materials, high technology services, new energy and energy conservation, resources and environment, advanced manufacturing and automation, the new generation high technology characterized by intelligent technology and quantum technology has emerged. It has become the frontier of a new round of scientific and technological revolution and industrial change, which is being arranged by the world's major scientific and technological powers, and has become a strategic field related to the national security and high-quality development of society and economy. Following guidance of Development Planning of New Generation Artificial Intelligence (Issued by the State Council of the People's Republic of China, [2017] No. 35), China's artificial intelligence industry has developed rapidly. In 2020, the industrial scale reached 160.69 billion CNY (Chinese Yuan), an increase of $126.8 \%$ over 2017 (CCID Consulting Co. Ltd.), and the industrial layout has been basically formed. At the same time, thanks to the investment and political support from government, the quantum communication, quantum computing, quantum measurement and other subdivision industries related to quantum technology are expected to enter a period of rapid development, which is expected to seize the global commanding height of the development of quantum technology. On October 21, 2020, the Ministry of Science and Technology of the People's Republic of China proposed to strengthen the forward-looking deployment, vigorously develop the new generation high-tech characterized by intelligent technology and quantum technology, create the first mover advantage of China's high-tech, accelerate the cultivation of new generation high-tech industry, and further expand the new momentum of development.

Increasing financial support for the new generation high-tech industry has important practical significance for accelerating the cultivation and development of the new generation high-tech industry. With constraint of financial resources, not only form a sound financial support system for the new generation high-tech industry, but also pay attention to the efficiency of financial support. On the one hand, through government guidance and market operation, give full play to the advantages and potential of digital inclusive finance, improve the financing availability of new generation high-tech enterprises, and reduce the financing cost of enterprises. On the other hand, actively guide the new generation high-tech enterprises to innovate management, improve quality and efficiency, comprehensively improve their technological innovation capability and management level, so as to effectively improve the financial support efficiency of new generation high-tech industry. Therefore, to clarify the influencing factors of financial support efficiency of new generation high-tech industry is helpful to improve the financial support efficiency of new generation high-tech industry and increase the financial support for the new generation high-tech industry. 
In recent decade, only few researches have discussed the influencing factors of financial support efficiency of new generation high-tech industry. Some related researches mainly focus on the analysis of technological innovation performance of venture capital (Kortum \& Lerner, 2000; Engel \& Keilbach, 2007; Chemmanur, Krishnan, \& Nandy, 2011). Other related researches mainly focus on the analysis of the influencing factors of financial support efficiency of strategic emerging industry (Wu \& Yao, 2015; Xie \& Ma, 2016; Zeng \& Geng, 2019; Xiong \& Lin, 2010; Xiong, Zhan, \& Lin, 2011; Zhai, 2012; Ma, 2013; Ma \& Wang, 2016; Wang, 2016; Huang \& Wen, 2017; Li \& Yang, 2017; Chen et al, 2020). Only Wu, Li \& Hua (2016) and Jiang (2020) preliminarily discuss the influencing factors of financial support efficiency of high-tech industry and artificial intelligence industry respectively. In view of this, from the perspective of the subject (enterprise) in which financial resources are invested, this paper selects 192 listed companies in quantum communication and artificial intelligence concept plates in Chinese stock market as samples, and uses the DEA-BCC model and Tobit model to empirically analyze the influencing factors of financial support efficiency of new generation high-tech listed companies based on the original data of 2015-2019.

This paper is structured as follows: Section 2 proposes the research hypotheses. Section 3 constructs the empirical model, selects the variables, research samples and data. Section 4 describes the regression results of Tobit model and Section 5 concludes this paper.

\section{Theoretical Analysis and Research Hypothesis}

Profitability refers to the ability of an enterprise to obtain operating profits, which is usually expressed as the amount and level of income obtained by enterprise in a certain period. In general, the stronger the profitability of enterprise is, the higher the efficiency of financial support is. Wang (2016) found that the operating cost profit margin is significantly positively correlated with the financial support efficiency of strategic emerging industry. Li, Zhang \& Zhou (2015) found that there is a low positive correlation between the return on equity (ROE) and the capital market financing efficiency of strategic emerging industry. The empirical results of Jiang (2020) showed that the ROE is positively correlated with the financing efficiency of artificial intelligence industry. Based on the above analysis, we propose the hypothesis:

$H 1$ : the profitability has a significant positive impact on the financial support efficiency of new generation high-tech listed companies.

Capital structure refers to the composition and proportion of all kinds of long-term capital (such as long-term debt capital and equity capital). Reasonable capital structure can reduce the comprehensive capital-cost rate, obtain financial leverage income, and improve enterprise value, so as to improve the efficiency of financial support. The empirical results of Wu \& Yao (2015) and Li \& Yang (2017) etc. showed that the asset liability ratio and the shareholder's equity ratio are significantly positively correlated with financial support efficiency of strateg- 
ic emerging industry. However, Xiong \& Lin (2010), Huang \& Wen (2017), Zeng \& Geng (2019) and Jiang (2020) etc. reached the opposite conclusion. In addition, Xiong, Zhan \& Lin (2011) and Wang (2016) etc. found that there is no significant correlation between the asset liability ratio and the financial support efficiency of strategic emerging industry. Considering that the new generation high-tech industry is still in the growth stage, we propose the hypothesis:

H2: the capital structure has a significant positive impact on the financial support efficiency of new generation high-tech listed companies.

Executive compensation means that in order to eliminate the conflict of interests between the executives and the shareholders, the shareholders implement compensation incentive plan for the executives to achieve incentive compatibility. Reasonable executive compensation can improve the company performance, so as to improve the efficiency of financial support. The empirical results of Kaplan (1994), Canarella \& Gasparyan (2008), Sigler (2011), Li, Sun \& Zhang (2008), Liu \& Wan (2013) and Shi et al. (2019) etc. showed that the executive compensation level is significantly positively correlated with the company performance. However, Main (1991), Li (2000) and Wei (2000) etc. found that there is no significant correlation between the executive compensation and the company performance. Considering that the new generation high-tech industry is still in the growth stage, we propose the hypothesis:

H3: the executive compensation has a significant positive impact on the financial support efficiency of new generation high-tech listed companies.

Growth is a quantitative description of the growth state of an enterprise. It refers to the sustainable development ability of an enterprise and reflects the development status of an enterprise' operation ability in a certain period. High growth is an important feature of the new generation high-tech enterprises, the growth level will have an important impact on the future business performance and development of enterprises, as well as the efficiency of financial support. Jin \& Huang (2018) found that the growth rate of main business income is significantly positively correlated with the financing efficiency of new third board enterprises. The empirical results of Jiang (2020) showed that there is a significant positive correlation between the growth rate of operating income and the financing efficiency of artificial intelligence industry. Based on the above analysis, we propose the hypothesis:

H4: the growth has a significant positive impact on the financial support efficiency of new generation high-tech listed companies.

Technological innovation is the source of the competitiveness of new generation high-tech enterprises, the accelerator to improve the economic benefits of new generation high-tech enterprises, and the basis for the survival and development of new generation high-tech enterprises. Enterprise's technological innovation capability is the overall function of product and process innovation capability. It is a systematic capability, which is an explicit capability expressed through technological innovation. The stronger the technological innovation 
capability of enterprise is, the better the enterprise performance is, so that the higher the efficiency of financial support is. The empirical results of Wang \& Tu (2012), Tang et al. (2014), Chen, Zou \& Liu (2015) and Lu \& Zhang (2021) etc. showed that the technological innovation capability has a significant positive impact on the performance of high-tech enterprises. Based on the above analysis, we propose the hypothesis:

H5: the technological innovation capability has a significant positive impact on the financial support efficiency of new generation high-tech listed companies.

Ownership concentration refers to the degree of ownership concentration shown by all shareholders of a company due to different shareholding ratios, which is a quantitative indicator reflecting the distribution of ownership, company stability and company structure. Appropriate ownership concentration can improve the company performance to a certain extent, thereby improving the efficiency of financial support. The empirical results of Huang \& Wen (2017) showed that the shareholding ratio of top ten shareholders has a significant positive correlation with the financial support efficiency of energy conservation and environmental protection industry. Jin \& Huang (2018) found that the shareholding ratio of the largest shareholder has a significant positive correlation with the financing efficiency of new third board enterprises. However, Wu \& Yao (2015) reached the opposite conclusion. Considering that the new generation high-tech industry is still in the growth stage, we propose hypothesis:

H6: the ownership concentration has a significant positive impact on the financial support efficiency of new generation high-tech listed companies.

Comprehensive leverage reflects the comprehensive effect of operating leverage and financial leverage. The effect of comprehensive leverage is generally measured by comprehensive leverage coefficient (= change rate of net profit/change rate of main business income). Enterprise risk includes operational risk and financial risk. The higher the comprehensive leverage coefficient is, the higher the total risk is, which has a negative impact on the efficiency of financial support. The empirical results of Zhou (2018) showed that the financial leverage has a significant negative correlation with the enterprise performance. Zeng \& Shao (2018) believed that in general, there is a significant positive correlation between the operating leverage and the operating risk. Yu \& Ye (2020) found that in the period of economic downturn, the financial leverage and the profitability of enterprises with low profitability present the characteristics of negative sensitivity, while the superposition and resonance of operating leverage and financial leverage form the "mystery of negative sensitivity". Based on the above analysis, we propose the hypothesis:

H7: the comprehensive leverage has a significant negative impact on the financial support efficiency of new generation high-tech listed companies.

Digital inclusive finance "generally refers to all actions to promote inclusive finance through the use of digital financial services" (G20 Advanced Principles of Digital Inclusive Finance). Digital inclusive finance can effectively reduce the 
threshold and cost of financial services, alleviate the financing constraints of enterprises, and reduce the financing cost of enterprises, so as to improve the efficiency of financial support. The empirical results of Yu \& Dou (2020), Liao, Hu \& Xiang (2020) and Ren (2020) etc. showed that the digital inclusive finance is especially helpful to alleviate the financing constraints of non-state-owned small and medium-sized enterprises, high-tech small and medium-sized enterprises, enterprises in central and western regions with no political background, small-scale enterprises and high-tech enterprises. Based on the above analysis, we propose the hypothesis:

H8: the regional digital inclusive finance has a significant positive impact on the financial support efficiency of new generation high-tech listed companies.

The level of regional economic development represents the status of natural conditions, socio-economic conditions and technical and economic policies in a certain region. The new generation high-tech industry needs to gather in the areas with perfect infrastructure, good industrial supporting conditions, strong ecological carrying capacity and rich scientific and technological resources to build characteristic industrial clusters. The high level of regional economic development and the strong basic support ability of industrial development help to improve the efficiency of financial support. Ma (2013) found that the location of listed companies in strategic emerging industry has a significant positive correlation with the financial support efficiency. The empirical results of Chen et al. (2020) showed that the location of listed companies in strategic emerging industry is positively correlated with the comprehensive efficiency, pure technical efficiency and scale efficiency of financial support. Based on the above analysis, we propose the hypothesis:

H9: the level of regional economic development has a significant positive impact on the financial support efficiency of new generation high-tech listed companies.

\section{Research Design}

\subsection{Empirical Model Setting}

In this study, we use DEA method to measure the financial support efficiency of new generation high-tech listed companies. Therefore, the explained variable is a limited dependent variable, whose value is greater than 0 and less than or equal to 1 . If the ordinary least squares (OLS) method is used to estimate the coefficients, it may cause inconsistency and bias. Tobit model belongs to dependent variable constrained model, it uses maximum likelihood method to estimate coefficients, which can better avoid the inconsistency and bias of coefficients estimation (Kalwij, 2003). Therefore, this paper uses the Tobit model to analyze the influencing factors of financial support efficiency of new generation high-tech listed companies. The specific form is as follows:

$$
y_{i t}^{*}=\beta_{0}+\sum_{j=1}^{k} \beta_{j} x_{j i t}+v_{i}+\varepsilon_{i t}
$$




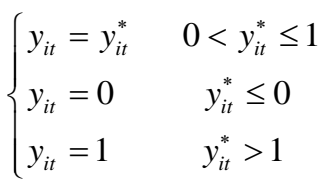

where $i$ represents the sample enterprise; $t$ represents the year; $y_{i t}^{*}$ is the latent variable. $y_{i t}$ is the observed actual explained variable; $x_{j i t}$ is the $j$-th explanatory variable $(j=1,2, \cdots, k) ; \quad \beta_{0}$ is the constant term; $\beta_{j}$ is the coefficient to be estimated of the $j$-th explanatory variable; $v_{i}$ is the individual effect term; $\varepsilon_{i t}$ is the random error term, $\varepsilon_{i t} \sim N\left(0, \sigma_{\varepsilon}^{2}\right)$, and independent of $v_{i}$.

\subsection{Variable Selection}

1) Explained variable: financial support efficiency of new generation high-tech listed companies

According to 13th Five-Year Development Planning of National High-tech Industrial Development Zones (Issued by the Ministry of Science and Technology of the People's Republic of China, Gao [2017] No. 90) and Opinions on Promoting High-quality Development of National High-tech Industrial Development Zones (Issued by the State Council of the People's Republic of China, [2020] No. 7), based on the relevant research results, and following the principles of selecting indicators, such as scientific, objective, systematic, functional, dynamic, relative independence, feasibility (or operability), comparability and so on, this paper selected bank loans (the sum of long-term and short-term loans in the enterprise balance sheet), stock financing (the sum of the amount of IPO and the amount of allotment and additional issuance in the financial report), bond financing (the sum of long-term and short-term bonds in the enterprise balance sheet), government subsidies (the amount of government subsidies in the notes to the enterprise's financial statement) and venture capital (the product of the number of equity of venture capital institutions and IPO price) as the input indicators to measure the financial support efficiency of new generation high-tech listed companies (note: due to the low amount of enterprise property insurance, this paper did not consider insurance). In addition, this paper selected the enterprise net profit (the net profit in the enterprise profit statement) and tax amount (the sum of various taxes in the notes to the enterprise financial statement) as the output indicators to measure the financial support efficiency of new generation high-tech listed companies.

In order to meet the requirements of DEAP Version 2.1 software for input data, before measuring the efficiency of financial support, the original data were standardized. The calculation formula is:

$$
x_{i j}^{*}=0.1+\frac{x_{i j}-\min \left(x_{j}\right)}{\max \left(x_{j}\right)-\min \left(x_{j}\right)} \times 0.9
$$

where $\max \left(x_{j}\right)$ and $\min \left(x_{j}\right)$ are the maximum and minimum values of the $j$-th indicator, respectively. 
According to the original index data after standardization, DEAP Version 2.1 software was used to measure the comprehensive technical efficiency (TE), pure technical efficiency (PTE) and scale efficiency (SE) of financial support of 192 sample enterprises from 2015 to 2019 by DEA-BCC model (Banker, Charnes, \& Cooper, 1984). Where SE = TE/PTE. Referring to Bi \& Li (2019), the DEA evaluation value was divided into four intervals from low to high: $(0,0.5),[0.5,0.8)$, $[0.8,1)$ and 1 , so as to obtain the distribution of comprehensive technical efficiency, pure technical efficiency and scale efficiency as shown in Tables 1-3 (specific data backup).

2) Explanatory variable

This paper selected the profitability, capital structure, executive compensation, growth, technological innovation capability, ownership concentration, comprehensive leverage, regional digital inclusive finance level and regional economic development level of new generation high-tech listed companies as

Table 1. Distribution of TE of financial support of 192 sample enterprises from 2015 to 2019.

\begin{tabular}{cccccccccccc}
\hline & \multicolumn{2}{c}{2015} & \multicolumn{2}{c}{2016} & \multicolumn{2}{c}{2017} & \multicolumn{2}{c}{2018} & \multicolumn{2}{c}{2019} \\
\cline { 2 - 11 } TEs & $\begin{array}{c}\text { Quantities } \\
\text { (piece) }\end{array}$ & $\begin{array}{c}\text { Proportions } \\
(\%)\end{array}$ & $\begin{array}{c}\text { Quantities } \\
\text { (piece) }\end{array}$ & $\begin{array}{c}\text { Proportions } \\
(\%)\end{array}$ & $\begin{array}{c}\text { Quantities } \\
\text { (piece) }\end{array}$ & $\begin{array}{c}\text { Proportions } \\
(\%)\end{array}$ & $\begin{array}{c}\text { Quantities } \\
(\text { piece) })\end{array}$ & $\begin{array}{c}\text { Proportions } \\
(\%)\end{array}$ & $\begin{array}{c}\text { Quantities } \\
\text { (piece) }\end{array}$ & $\begin{array}{c}\text { Proportions } \\
(\%)\end{array}$ \\
\hline 1 & 4 & 2.08 & 8 & 4.17 & 5 & 2.60 & 12 & 6.25 & 9 & 4.69 \\
{$[0.8,1)$} & 5 & 2.60 & 138 & 71.88 & 4 & 2.08 & 142 & 73.96 & 99 & 51.56 \\
{$[0.5,0.8)$} & 179 & 93.23 & 43 & 22.40 & 176 & 91.67 & 38 & 19.79 & 82 & 42.71 \\
$(0,0.5)$ & 4 & 2.08 & 3 & 1.56 & 7 & 3.65 & 0 & 0.00 & 2 & 1.04 \\
\hline
\end{tabular}

Table 2. Distribution of PTE of financial support of 192 sample enterprises from 2015 to 2019.

\begin{tabular}{ccccccccccc}
\hline & \multicolumn{2}{c}{2015} & \multicolumn{2}{c}{2016} & \multicolumn{2}{c}{2017} & \multicolumn{2}{c}{2018} & \multicolumn{2}{c}{2019} \\
\cline { 2 - 12 } PTEs & $\begin{array}{c}\text { Quantities } \\
\text { (piece) }\end{array}$ & $\begin{array}{c}\text { Proportions } \\
(\%)\end{array}$ & $\begin{array}{c}\text { Quantities } \\
\text { (piece) }\end{array}$ & $\begin{array}{c}\text { Proportions } \\
(\%)\end{array}$ & $\begin{array}{c}\text { Quantities } \\
\text { (piece) }\end{array}$ & $\begin{array}{c}\text { Proportions } \\
(\%)\end{array}$ & $\begin{array}{c}\text { Quantities } \\
\text { (piece) }\end{array}$ & $\begin{array}{c}\text { Proportions } \\
(\%)\end{array}$ & $\begin{array}{c}\text { Quantities } \\
(\text { piece) }\end{array}$ & $\begin{array}{c}\text { Proportions } \\
(\%)\end{array}$ \\
\hline 1 & 181 & 94.27 & 175 & 91.15 & 174 & 90.63 & 174 & 90.63 & 177 & 92.19 \\
{$[0.8,1)$} & 10 & 5.21 & 16 & 8.33 & 16 & 8.33 & 17 & 8.85 & 13 & 6.77 \\
{$[0.5,0.8)$} & 1 & 0.52 & 1 & 0.52 & 2 & 1.04 & 1 & 0.52 & 2 & 1.04 \\
$(0,0.5)$ & 0 & 0.00 & 0 & 0.00 & 0 & 0.00 & 0 & 0.00 & 0 & 0.00 \\
\hline
\end{tabular}

Table 3. Distribution of SE of financial support of 192 sample enterprises from 2015 to 2019.

\begin{tabular}{|c|c|c|c|c|c|c|c|c|c|c|}
\hline \multirow[b]{2}{*}{ SEs } & \multicolumn{2}{|c|}{2015} & \multicolumn{2}{|c|}{2016} & \multicolumn{2}{|c|}{2017} & \multicolumn{2}{|c|}{2018} & \multicolumn{2}{|c|}{2019} \\
\hline & $\begin{array}{l}\text { Quantities } \\
\text { (piece) }\end{array}$ & $\begin{array}{c}\text { Proportions } \\
\text { (\%) }\end{array}$ & $\begin{array}{l}\text { Quantities } \\
\text { (piece) }\end{array}$ & $\begin{array}{c}\text { Proportions } \\
\text { (\%) }\end{array}$ & $\begin{array}{l}\text { Quantities } \\
\text { (piece) }\end{array}$ & $\begin{array}{c}\text { Proportions } \\
\text { (\%) }\end{array}$ & $\begin{array}{l}\text { Quantities } \\
\text { (piece) }\end{array}$ & $\begin{array}{c}\text { Proportions } \\
\text { (\%) }\end{array}$ & $\begin{array}{c}\text { Quantities } \\
\text { (piece) }\end{array}$ & $\begin{array}{c}\text { Proportions } \\
\text { (\%) }\end{array}$ \\
\hline 1 & 4 & 2.08 & 8 & 4.17 & 5 & 2.60 & 12 & 6.25 & 9 & 4.69 \\
\hline$[0.8,1)$ & 5 & 2.60 & 142 & 73.96 & 4 & 2.08 & 148 & 77.08 & 103 & 53.65 \\
\hline$[0.5,0.8)$ & 179 & 93.23 & 40 & 20.83 & 177 & 92.19 & 32 & 16.67 & 79 & 41.15 \\
\hline$(0,0.5)$ & 4 & 2.08 & 2 & 1.04 & 6 & 3.13 & 0 & 0.00 & 1 & 0.52 \\
\hline
\end{tabular}


explanatory variables. Where the profitability was measured by the profit margin of main business (PMMB). The capital structure was measured by the asset liability ratio (ALR). The top three executives' total compensation (TTEC) was used to measure the executive compensation. The growth was measured by the net profit growth rate (NPGR). The technological innovation capability was measured by the intangible assets (IA). The shareholding ratio of top five shareholders (SRTFS) was used to measure the ownership concentration. The comprehensive leverage level was measured by the comprehensive leverage coefficient (CLC). The regional digital inclusive finance index (DIFI) was used to measure the level of regional digital inclusive finance. In addition, the level of regional economic development was measured by the regional per capita GDP (PCGDP).

\subsection{Research Samples and Data Sources}

This paper selected 49 listed companies in the concept plate of quantum communication and 143 listed companies in the concept plate of artificial intelligence from East Money website (https://www.eastmoney.com/) as research samples. The number of samples is 192, and the sample interval was set to 2015-2019. Where the original data of financial support efficiency measurement index of new generation high-tech listed companies came from the annual reports of 192 listed companies. The original data of profit margin of main business, asset liability ratio, top three executives' total compensation, net profit growth rate, intangible assets, shareholding ratio of top five shareholders and comprehensive leverage coefficient were from CSMAR database and Wind database. The original data of regional digital inclusive finance index came from the digital finance research center of Peking University. The original data of regional per capita GDP came from China Statistical Yearbook. In addition, the missing data were estimated by mean interpolation and manual interpolation. Descriptive statistics of all variables were shown in Table 4.

\section{Empirical Analyses}

\subsection{Hausman Test}

Hausman test is an econometric method to select fixed-effects model and random-effects model when using panel data (Hausman, 1978). Using the comprehensive technical efficiency, pure technical efficiency and scale efficiency as explained variable respectively, the Hausman test on sample data was conducted with the help of Stata16.1 software. When the explained variable is comprehensive technical efficiency, the $\mathrm{P}$ value is $0.0412<0.05$, it means that the Hausman test is significant at the $5 \%$ significance level, then the original hypothesis is rejected and the fixed-effects model is selected. When the explained variable is pure technical efficiency, the $\mathrm{P}$ value is $0.2791>0.10$, it means that the Hausman test is not significant at the $10 \%$ significance level, then the original hypothesis is 
Table 4. Descriptive statistics of variables.

\begin{tabular}{cccccc}
\hline Variables (Unit) & $\begin{array}{c}\text { Numbers of } \\
\text { Samples }\end{array}$ & $\begin{array}{c}\text { Average } \\
\text { Values }\end{array}$ & $\begin{array}{c}\text { Standard } \\
\text { Deviations }\end{array}$ & $\begin{array}{c}\text { Minimum } \\
\text { Values }\end{array}$ & $\begin{array}{c}\text { Maximum } \\
\text { Values }\end{array}$ \\
\hline TE & 960 & 0.773 & 0.120 & 0.258 & 1.000 \\
PTE & 960 & 0.993 & 0.033 & 0.596 & 1.000 \\
SE & 960 & 0.778 & 0.117 & 0.258 & 1.000 \\
PMMB (\%) & 960 & 0.348 & 0.184 & 0.025 & 0.958 \\
ALR (\%) & 960 & 35.606 & 17.138 & 1.969 & 86.116 \\
TTEC (million CNY) & 960 & 2.630 & 2.087 & 0.183 & 24.231 \\
NPGR (\%) & 960 & 14.851 & 476.212 & -2567.669 & $10,326.137$ \\
IA (100 million CNY) & 960 & 5.456 & 21.909 & 0.007 & 269.829 \\
SRTFS (\%) & 960 & 0.489 & 0.155 & 0.070 & 1.000 \\
CLC & 960 & 2.105 & 5.696 & 0.164 & 132.328 \\
DIFI & 960 & 287.340 & 40.670 & 193.290 & 377.730 \\
PCGDP (10 thousand & 960 & 9.104 & 3.117 & 2.616 & 16.421 \\
CNY) & & & & &
\end{tabular}

accepted and the random-effects model is selected. In addition, when the explained variable is scale efficiency, the $\mathrm{P}$ value is $0.0356<0.05$, it means that the Hausman test is significant at the $5 \%$ significance level, then the original hypothesis is rejected and the fixed-effects model is selected.

\subsection{Regression Results and Analysis of Tobit Model}

According to the Hausman test results, using Stata16.1 software, this paper used respectively comprehensive technical efficiency, pure technical efficiency and scale efficiency as explained variable, the coefficients of Equation (1) were estimated by using correspondingly fixed-effects model, random-effects model and fixed-effects model, and the regression results of Tobit model were obtained as shown in Table 5.

It can be seen from Table 5 that the regression coefficients of the profit margin of main business to the comprehensive technical efficiency, pure technical efficiency and scale efficiency are not significant, indicating that the impact of profit margin of main business on financial support efficiency is not obvious, which may be related to the low profitability of new generation high-tech listed companies at present. Therefore, the original hypothesis $H 1$ is rejected.

The regression coefficients of the asset liability ratio to the comprehensive technical efficiency, pure technical efficiency and scale efficiency are not significant, which indicates that the impact of asset liability ratio on financial support efficiency is not obvious. This may be related to the fact that the new generation high-tech listed companies are still facing certain debt financing constraints at this stage. Therefore, the original hypothesis $H 2$ is rejected. 
Table 5. Regression results of Tobit model.

\begin{tabular}{|c|c|c|c|c|c|c|}
\hline Variables & TEs & $\mathrm{P}>\mathrm{z}$ & PTEs & $\mathrm{P}>\mathrm{z}$ & SEs & $\mathrm{P}>\mathrm{z}$ \\
\hline PMMB & $\begin{array}{l}0.015136 \\
(0.5200)\end{array}$ & 0.6000 & $\begin{array}{l}-0.062033 \\
(-0.6800)\end{array}$ & 0.4960 & $\begin{array}{l}0.013382 \\
(0.4500)\end{array}$ & 0.6560 \\
\hline ALR & $\begin{array}{l}0.000118 \\
(0.3900)\end{array}$ & 0.6940 & $\begin{array}{l}-0.001327 \\
(-1.4100)\end{array}$ & 0.1590 & $\begin{array}{l}0.000161 \\
(0.5200)\end{array}$ & 0.6040 \\
\hline TTEC & $\begin{array}{c}0.007278^{\star * *} \\
(3.1500)\end{array}$ & 0.0020 & $\begin{array}{l}-0.002647 \\
(-0.4000)\end{array}$ & 0.6890 & $\begin{array}{c}0.007235^{\star * *} \\
(3.0200)\end{array}$ & 0.0030 \\
\hline NPGR & $\begin{array}{c}0.000007 \\
(0.8900)\end{array}$ & 0.3730 & $\begin{array}{c}0.000060^{\star *} \\
(1.9700)\end{array}$ & 0.0490 & $\begin{array}{c}0.000009 \\
(1.2000)\end{array}$ & 0.2310 \\
\hline IA & $\begin{array}{c}0.000378^{*} \\
(1.6600)\end{array}$ & 0.0980 & $\begin{array}{c}-0.001196^{\star *} \\
(-2.0300)\end{array}$ & 0.0420 & $\begin{array}{l}0.000135 \\
(0.5700)\end{array}$ & 0.5690 \\
\hline SRTFS & $\begin{array}{c}0.116103^{* * *} \\
(3.8200)\end{array}$ & 0.0000 & $\begin{array}{c}0.410425^{* * *} \\
(3.2800)\end{array}$ & 0.0010 & $\begin{array}{c}0.128605^{\star * *} \\
(4.0700)\end{array}$ & 0.0000 \\
\hline CLC & $\begin{array}{l}0.000021 \\
(0.0300)\end{array}$ & 0.9750 & $\begin{array}{c}-0.002804^{* \star} \\
(-2.2400)\end{array}$ & 0.0250 & $\begin{array}{l}-0.000300 \\
(-0.4300)\end{array}$ & 0.6650 \\
\hline DIFI & $\begin{array}{c}0.000631^{* * *} \\
(5.0200)\end{array}$ & 0.0000 & $\begin{array}{l}0.000030 \\
(0.0900)\end{array}$ & 0.9270 & $\begin{array}{c}0.000655^{\star * *} \\
(5.1000)\end{array}$ & 0.0000 \\
\hline PCGDP & $\begin{array}{c}0.003476^{*} \\
(1.8000)\end{array}$ & 0.0710 & $\begin{array}{l}-0.002703 \\
(-0.4700)\end{array}$ & 0.6390 & $\begin{array}{l}0.003024 \\
(1.5100)\end{array}$ & 0.1300 \\
\hline Constant term & $\begin{array}{l}0.479975 \\
(13.1200)\end{array}$ & 0.0000 & $\begin{array}{l}1.192432 \\
(10.8500)\end{array}$ & 0.0000 & $\begin{array}{l}0.467023 \\
(12.3900)\end{array}$ & 0.0000 \\
\hline
\end{tabular}

Note: (1) “***» indicates $\mathrm{P}<0.01$, “**” indicates $\mathrm{P}<0.05$, "*” indicates $\mathrm{P}<0.1$; (2) The value in parenthesis () is $z$.

The regression coefficient of the top three executives' total compensation to the comprehensive technical efficiency is significantly positive at the level of $1 \%$, where the regression coefficient to the scale efficiency is significantly positive at the level of $1 \%$, but the regression coefficient to the pure technical efficiency is not significant, which indicates that the top three executives' total compensation has a significant positive impact on the financial support efficiency to a certain extent. Therefore, the original hypothesis $H 3$ is accepted.

The regression coefficient of the net profit growth rate to the comprehensive technical efficiency is not significant, where the regression coefficient to the pure technical efficiency is significantly positive at the level of $5 \%$, but the regression coefficient to the scale efficiency is not significant, indicating that the net profit growth rate has only a certain positive impact on the financial support efficiency. This may be related to the fact that the new generation high-tech listed companies pay more attention to improving their management and technical level at this stage. Therefore, the original hypothesis $H 4$ is rejected.

The regression coefficient of the intangible assets to the comprehensive technical efficiency is significantly positive at the level of $10 \%$, where the regression coefficient to the pure technical efficiency is significantly negative at the level of $5 \%$, but the regression coefficient to the scale efficiency is not significant, indi- 
cating that the intangible assets have a significant positive impact on the financial support efficiency to a certain extent. Therefore, the original hypothesis $H 5$ is accepted.

The regression coefficients of the shareholding ratio of top five shareholders to the comprehensive technical efficiency, pure technical efficiency and scale efficiency are significantly positive at the level of $1 \%$, which indicates that the shareholding ratio of top five shareholders has a significant positive impact on the financial support efficiency. Therefore, the original hypothesis $H 6$ is accepted.

The regression coefficient of the comprehensive leverage coefficient to the comprehensive technical efficiency is not significant, where the regression coefficient to the pure technical efficiency is significantly negative at the level of 5\%, but the regression coefficient to the scale efficiency is not significant, indicating that the comprehensive leverage coefficient has only a certain negative impact on the financial support efficiency. This may be related to the fact that the new generation high-tech listed companies pay more attention to control management and technology risks at this stage. Therefore, the original hypothesis $H 7$ is rejected.

The regression coefficient of the regional digital inclusive financial index to the comprehensive technical efficiency is significantly positive at the level of $1 \%$, where the regression coefficient to the scale efficiency is significantly positive at the level of $1 \%$, but the regression coefficient to the pure technical efficiency is not significant, which indicates that the regional digital inclusive financial index has a significant positive impact on the financial support efficiency to a certain extent. Therefore, the original hypothesis $H 8$ is accepted.

The regression coefficient of the regional per capita GDP to the comprehensive technical efficiency is significantly positive at the level of $10 \%$, where the regression coefficients to the pure technical efficiency and scale efficiency are not significant, which indicates that the regional per capita GDP has a significant positive impact on the financial support efficiency to a certain extent. Therefore, the original hypothesis $H 9$ is accepted.

To sum up, the top three executives' total compensation, intangible assets, shareholding ratio of top five shareholders, regional digital inclusive financial index and regional per capita GDP have a significant impact on the resource allocation ability, resource use efficiency, etc. of the new generation high-tech listed companies, thus have a significant impact on the comprehensive technical efficiency. Where, the net profit growth rate, intangible assets, shareholding ratio of top five shareholders and comprehensive leverage coefficient have a significant impact on the management, technology, etc. of the new generation high-tech listed companies, thus have a significant impact on the pure technical efficiency; the top three executives' total compensation, shareholding ratio of top five shareholders and regional digital inclusive financial index have a significant impact on the scale factor of the new generation high-tech listed companies, thus 
have a significant impact on the scale efficiency. In summary, the original hypothesis $H 3, H 5, H 6, H 8$ and $H 9$ are accepted. However, the original hypothesis $H 1, H 2, H 4$ and $H 7$ are rejected.

\subsection{Robustness Test}

In order to test the robustness of the regression results of Tobit model, this paper replaced Tobit model with static panel data model, and used the static panel data model to estimate the coefficients with the comprehensive technical efficiency, pure technical efficiency and scale efficiency as explained variable respectively. The results show that the symbols of regression coefficients of shareholding ratio of top five shareholders, top three executives' total compensation, regional digital inclusive financial index, intangible assets, regional per capita GDP and other important variables are completely the same as those of Tobit model, with a slight difference in significance, indicating that the regression results of Tobit model are more robust.

\section{Conclusions}

According to the regression results and analysis of Tobit model in Section 4.2, we can obtain the following conclusions:

1) The ownership concentration has a significant positive impact on the financial support efficiency of new generation high-tech listed companies, which is consistent with the empirical conclusions of Huang \& Wen (2017) and Jin \& Huang (2018).

2) The executive compensation has a significant positive impact on the financial support efficiency of new generation high-tech listed companies, but has no significant impact on the pure technical efficiency, which is generally consistent with the empirical conclusions of Kaplan (1994), Canarella \& Gasparyan (2008), Sigler (2011), Li, Sun \& Zhang (2008), Liu \& Wan (2013) and Shi et al. (2019).

3) The level of regional digital inclusive finance has a significant positive impact on the financial support efficiency of new generation high-tech listed companies, but has no significant impact on the pure technical efficiency, which is generally consistent with the empirical conclusions of Yu \& Dou (2020), Liao, Hu \& Xiang (2020) and Ren (2020).

4) The technological innovation capability has a significant positive impact on the financial support efficiency of new generation high-tech listed companies, but has no significant impact on the scale efficiency, which is generally consistent with the empirical conclusions of Wang \& Tu (2012), Tang et al. (2014), Chen, Zou \& Liu (2015) and Lu \& Zhang (2021).

5) The level of regional economic development has a significant positive impact on the financial support efficiency of new generation high-tech listed companies, but has no significant impact on the pure technical efficiency and scale efficiency, which is consistent with the empirical conclusions of Ma (2013) and Chen et al. (2020). 
6) The growth has no significant positive effect on the financial support efficiency of new generation high-tech listed companies, but has a significant positive impact on the pure technology efficiency, this is different from the empirical conclusions of Jiang (2020) and Jin \& Huang (2018) in the significance.

7) The comprehensive leverage has no significant negative impact on financial support efficiency of new generation high-tech listed companies, but has significant negative impact on the pure technical efficiency, this is different from the empirical conclusions of Zhou (2018) and Yu \& Ye (2020) in the significance.

8) The profitability has no significant positive impact on the financial support efficiency of new generation high-tech listed companies, this is different from the empirical conclusions of Wang (2016), Jiang (2020) and Li, Zhang \& Zhou (2015) in the significance.

9) The capital structure has no significant positive impact on the financial support efficiency of new generation high-tech listed companies, which is consistent with the empirical conclusions of Xiong, Zhan \& Lin (2011) and Wang (2016), however, this is different from the empirical conclusions of Wu \& Yao (2015) and Li \& Yang (2017) in the significance.

On the whole, the ownership concentration, executive compensation and regional digital inclusive financial level are the main factors influencing the financial support efficiency of new generation high-tech listed companies, followed by the technological innovation capability and regional economic development level. The impact of growth and comprehensive leverage on the financial support efficiency of new generation high-tech listed companies is relatively limited, while the impact of profitability and capital structure on the financial support efficiency of new generation high-tech listed companies is not obvious.

This paper made a theoretical analysis and empirical test on the influencing factors of financial support efficiency of new generation high-tech listed companies. It should be noticed that the comprehensive technical efficiency (TE), pure technical efficiency (PTE) and scale efficiency (SE) of financial support of 192 sample enterprises from 2015 to 2019 were measured by using the DEA-BCC model in Section 3.2. However, the DEA-BCC model can only compare the efficiency values of different decision-making units in the same period statically, but cannot measure the dynamic changes of efficiency values in different periods. Therefore, using the DEA Malmquist index model to measure the dynamic changes of the financial support efficiency of new generation high-tech enterprises, and investigating their influencing factors, which is worthy of further study in the future. In addition, this paper proposed nine hypotheses, and tested nine factors that affect the financial support efficiency of new generation high-tech listed companies. However, this leads to the research of this paper is too broad. Therefore, reducing the hypotheses to conduct more in-depth research remains to be completed in the future.

According to the above research conclusions, we can put forward the following policy recommendations: 
1) In terms of input, by doing a good job in the top-level design and grassroots pilot, grasping the relationship between financial innovation and risk prevention, improving the digital inclusive financial infrastructure, strengthening the digital inclusive financial education and other measures, a digital inclusive financial system with banking financial institutions as the center, Internet enterprises as the support, non-banking financial institutions as the supplement, continuous empowerment of financial technology, continuous improvement of infrastructure and sound institutional guarantee will accelerate its formation. Through government guidance and market operation, give full play to the advantages and potential of digital inclusive finance, effectively reduce the financing threshold and cost of new generation high-tech enterprises.

2) In terms of output, actively guide the new generation high-tech enterprises to fully digitalize the modern management ideas, methods, technologies and means, realize the digital management of enterprises, and pay attention to the reasonable regulation of ownership concentration and executive compensation level, so as to comprehensively improve enterprises performance. At the same time, give full play to the main role of the new generation high-tech enterprises in technological innovation and the resource advantages of industry, university, research and utilization, strengthen the policy incentives of technological innovation with tax incentives and innovation subsidies as the core, and accelerate the development of new generation high-tech industrial clusters, so as to comprehensively improve the technological innovation capability of new generation high-tech industry.

\section{Acknowledgements}

To the Regional Project of National Natural Science Foundation of China (71861003) and the Innovative Exploration and New Academic Seedlings Project of Guizhou University of Finance and Economics (Guizhou-Science Cooperation Platform Talents [2018] 5774-016) for their support.

\section{Conflicts of Interest}

The authors declare no conflicts of interest regarding the publication of this paper.

\section{References}

Banker, R. D., Charnes, A., \& Cooper, W. W. (1984). Some Models for Estimating Technical and Scale Inefficiencies in Data Envelopment Analysis. Management Science, 30, 1078-1092. https://doi.org/10.1287/mnsc.30.9.1078

Bi, C., \& Li, X. W. (2019). Research on Equity Financing Efficiency and Influencing Factors of New Third Board Enterprises. Communication of Finance and Accounting, No. $35,31-34$.

Canarella, G., \& Gasparyan, A. (2008). New Insights into Executive Compensation and Firm Performance: Evidence from A Panel of "New Economy" Firms, 1996-2002. Ma- 
nagerial Finance, 34, 537-554. https://doi.org/10.1108/03074350810874064

Chemmanur, T. J., Krishnan, K., \& Nandy, D. K. (2011). How Does Venture Capital Financing Improve Efficiency in Private Firms? A Look Beneath the Surface. Review of Finance Studies, 24, 4037-4090. https://doi.org/10.1093/rfs/hhr096

Chen, S., Zou, Z. M., \& Liu, D. (2015). Effects of R\&D Investment and Technology Innovation Capability Life Cycle on Firm Performance. Science \& Technology Progress and Policy, 32, 72-78.

Chen, X. R., Han, J. W., Ren, A. H., \& Sun, Z. Y. (2020). Financial Support Efficiency of Strategic Emerging Industries: An Empirical Study of 237 Listed Companies in Beijing-Tianjin-Hebei Region. Journal of Finance and Economics, No. 5, 81-88.

Engel, D., \& Keilbach, M. (2007). Firm Level Implications of Early-stage Venture Capital Investment: An Empirical Investigation. Journal of Empirical Finance, 14, 150-167. https://doi.org/10.1016/j.jempfin.2006.03.004

Hausman, J. A. (1978). Specification Tests in Econometrics. Econometrica, 46, 1251-1271. https://doi.org/10.2307/1913827

Huang, X. Y., \& Wen, L. R. (2017). Research on the Efficiency and Influencing Factors of Financial Support for the Enterprises in Energy-saving and Environmental Protection Industry. Economy and Management, 31, 45-50.

Jiang, Y. (2020). Research on Financing Efficiency and Influencing Factors of Artificial Intelligence Industry Based on Super-SBM and Logit Model. Journal of Industrial Technological Economics, 39, 131-136.

Jin, H., \& Huang, Y. (2018). An Analysis on Influencing Factors of Financing Efficiency of NEEQ Enterprises. Journal of Hangzhou Dianzi University (Social Sciences), 14, 24-29.

Kalwij, A. S. (2003). A Maximum Likelihood Estimator Based on First Differences for a Panel Data Tobit Model with Individual Specific Effects. Economics Letters, 81, 165-172. https://doi.org/10.1016/S0165-1765(03)00166-6

Kaplan, S. N. (1994). Top Executive Rewards and Firm Performance: A Comparison of Japan and the United States. Journal of Political Economy, 102, 510-546. https://doi.org/10.1086/261944

Kortum, S., \& Lerner, J. (2000). Assessing the Contribution of Venture Capital to Innovation. Journal of Economics, 31, 674-692. https://doi.org/10.2307/2696354

Li, M., \& Yang, Y. (2017). Research on Financial Support Efficiency and Influence Factors of Strategic Emerging Industries under the New Normal. Reform of Economic System, No. 1, 129-135.

Li, W. X., Zhang, D., \& Zhou, B. C. (2015). Research on the Influencing Factors of Capital Market Financing Efficiency of Strategic Emerging Industries-Empirical Data from A-Share Market. Commercial Accounting, No. 23, 28-29.

Li, Y. P., Sun, H., \& Zhang, Y. (2008). Executive Compensation Incentives, Strategic M \& A and Corporate Performance-An Empirical Study from Chinese A-Share Listed Companies. Management World, No. 12, 177-179.

Li, Z. Q. (2000). Incentive Mechanism and Corporate Performance-An Empirical Study Based on Listed Companies. Accounting Research, No. 1, 24-30.

Liao, J. L., Hu, Y., \& Xiang, H. J. (2020). Could Digital Financial Inclusion Alleviate the Financing Constraints of Enterprises? Based on the Regulating Effect of Corporate Social Responsibility. Journal of Yunnan University of Finance and Economics, 36, 73-87.

Liu, S. W., \& Wan, D. Y. (2013). Executive Compensation Affects Firm Performance: The 
Empirical Comparative Study on State-Owned and Non-State-Owned Enterprises. China Soft Science, No. 2, 90-101.

Lu, X. J., \& Zhang, X. R. (2021). Information Capital, Technological Innovation Capability and Enterprise Performance. Friends of Accounting, No. 9, 64-70.

Ma, J. W. (2013). Research on the Differences of Financial Support Efficiency of Seven Strategic Emerging Industries in China and Its Influencing Factors-Based on the Empirical Evidence of Listed Companies. Reform of Economic System, No. 3, 133-137.

Ma, J. W., \& Wang, J. H. (2016). Efficiency Evaluation and Influencing Factors in Financial Support of Strategic Emerging Industries in Jiangsu Province. Forum on Science and Technology in China, No. 8, 31-37.

Main, B. G. M. (1991). Top Executive Pay and Performance. Managerial and Decision Economics, 12, 219-229. https://doi.org/10.1002/mde.4090120304

Ren, X. Y. (2020). Can the Development of Digital Inclusive Finance Ease the Financing Constraints of Enterprises? Modern Economic Research, No. 10, 65-75.

Shi, J. Y., Guo, S. C., Zhang, Q. W., \& Chen, T. T. (2019). Executive Compensation, Mandatory Turnover and Corporate Performance. East China Economic Management, 33, 54-62.

Sigler, K. J. (2011). CEO Compensation and Company Performance. Business and Economics Journal, 31, 1-8.

Tang, Y., Zhang, H. Q., Li, P., \& Guo, Y. J. (2014). An Empirical Analysis of Social Capital, Enterprise Technological Innovation Ability and Enterprise Performance. Statistics \& Decision, No. 16, 102-104.

Wang, S. H. (2016). Analysis on Financial Support Efficiency of Strategic Emerging Industries-An Empirical Study Based on Listed Companies in Gansu Province. Journal of Commercial Economics, No. 24, 170-172.

Wang, T. N., \& Tu, Y. M. (2012). Influence of Technology Innovation Capability on Enterprise's Performance under Regulation of Management Innovation Capability. Technology Economics, 31, 25-32.

Wei, G. (2000). Incentives for Top-Management and Performance of Listed Companies. Economic Research Journal, No. 3, 32-39+64-80.

Wu, L., Li, Y. L., \& Hua, R. (2016). Research on the Efficiency of Financial Support for the Development of China's High-Tech Industry Based on DEA Two-Stage Model. Review of Economic Research, No. 67, 63-68.

Wu, N., \& Yao, J. Z. (2015). Research on the Impact of Corporate Capital Structure on Financing Efficiency-Based on the Empirical Data of Biomedical Industry. Communication of Finance and Accounting, No. 2, 38-40.

Xie, T. T., \& Ma, J. (2016). Research on Financing Efficiency and Its Influencing Factors of Listed Companies in Energy Conservation and Environmental Protection Industry in Western China. Finance and Accounting Monthly, No. 24, 79-84.

Xiong, Z. D., \& Lin, X. (2010). Research on the Efficiency and Its Factors of Financial Support about Listed Companies in Strategic Emerging Industry. Economic Management Journal, 32, 26-33.

Xiong, Z. D., Zhan, B., \& Lin, X. (2011). The Efficiency of Financial Support about Strategic Emerging Industry Based on DEA and Logit Model. Systems Engineering, 29, $35-41$.

Yu, B., \& Ye, J. (2020). The Mystery of the Decline of Enterprise Profit Margin and the Rise of Financial Leverage Ratio. Jiangxi Social Sciences, 40, 60-74. 
Yu, P., \& Dou, J. X. (2020). Does the Development of Digital Inclusive Finance Ease the Financing Constraints of SMEs. Finance and Accounting Monthly, No. 3, 140-146.

Zeng, G., \& Geng, C. X. (2019). Empirical Study of Measurement of Financing Efficiency and Influencing Factors of Listed Companies in Strategic Emerging Industries: Based on Super SBM-Logit Model. Science and Technology Management Research, 39, 135-143.

Zeng, H. H., \& Shao, X. J. (2018). The Measurement of Operating Leverage and Operational Risk. Finance and Accounting Monthly, No. 23, 63-69.

Zhai, H. Y. (2012). Financial Support Efficiency of Listed Companies in the Strategic Emerging Industries. Securities Market Herald, No. 11, 20-25.

Zhou, L. L. (2018). Marketing Investment, Financial Leverage and Enterprise Performance. Communication of Finance and Accounting, No. 2, 27-29. 